\title{
A patient with primary amenorrhoea and hypertension: 17 á hydroxylase deficiency - a rare cause of congenital adrenal hyperplasia
}

\author{
W C K Jayawardena ${ }^{1}$, C N Antonypillai ${ }^{1}$ \\ Sri Lanka Journal of Diabetes, Endocrinology and Metabolism 2015; 5: 38-41
}

\begin{abstract}
A 26 year old girl, who is a product of a consanguineous marriage, presented with hypertension and hypokalaemia. She had a history of primary amenorrhoea with absent secondary sexual characteristics. Laboratory investigations revealed low levels of serum cortisol and low 17hydroxyprogesterone levels with high ACTH levels. Furthermore her adrenal androgens and oestradiol were low with elevated gonadotrophins. Chromosomal analysis revealed a male karyotype of 46, XY. All these clinical and laboratory data were consistent with the diagnosis of congenital adrenal hyperplasia (CAH) due to 17 alpha hydroxylase deficiency in a genotypic male. She was started on steroid replacement therapy while monitoring blood pressure, serum potassium levels and ACTH levels.
\end{abstract}

Key words: Congenital Adrenal Hyperplasia (CAH), $17 \alpha$ hydroxylase /17,20-lyase deficiency (17OHD)

\section{Introduction}

Congenital adrenal hyperplasia (CAH) comprises of a group of autosomal recessive disorders, caused by deficient adrenal corticosteroid biosynthesis. $17 \alpha$ hydroxylase/17,20-lyase deficiency (17OHD) is a rare form of $\mathrm{CAH}$ accounting for roughly $1 \%$ of all cases of $\mathrm{CAH}$, and most reports involve isolated cases from consanguineous families (1).

$17 \alpha$ hydroxylase $(17 \alpha \mathrm{OH})$ and 17,20 -lyase activities are catalyzed by microsomal cytochrome $\mathrm{P} 450 \mathrm{c} 17$ which is encoded by a single gene, CYP 17 (2) located on chromosome 10q24-q25 (3).

Deficiencies in $17 \alpha \mathrm{OH}$ and 17,20-lyase activities result in impaired synthesis of 17-hydroxyprogesterone and 17-hydroxypregnenolone resulting in low cortisol, androgens and oestrogens (Figure1). Decreased cortisol synthesis causes excessive secretion of ACTH due to loss of negative feedback, which results in excessive secretion of 17-deoxysteroids by the adrenal cortex, including the mineralocorticoids, deoxycorticosterone (DOC) and corticosterone. Accumulation of corticosterone and DOC results in severe hypokalaemic hypertension.

Sex steroid deficiency caused by loss of 17,20lyase deficiency manifests as under-virilization in male newborns and primary amenorrhoea in 46, XX individuals. There is lack of pubertal development due to hypergonadotrophic hypogonadism in both sexes (4).

\section{Case report}

A 26 year old girl was referred for further evaluation of hypertension and hypokalaemia, detected while being treated for a febrile illness. Her blood pressure ranged between $140 / 90$ and $170 / 100 \mathrm{mmHg}$ without any paroxysms and her potassium levels ranged between $2.5 \mathrm{mmol} / \mathrm{L}$ and $3.5 \mathrm{mmol} / \mathrm{L}$. She however, remained asymptomatic. She was a product of a consanguineous marriage and had two healthy siblings.

She had primary amenorrhoea with absent secondary sexual characteristics which had been investigated at the age of 17 years, with a hormonal profile and a diagnostic laparoscopy. She had elevated gonadotrophins with low oestradiol and testosterone levels and diagnostic laparoscopy had not shown a uterus, ovaries or testicles. At that time she had been normotensive and thus her potassium levels not evaluated. She had been treated with ethinyl oestradiol for a short duration but further diagnostic procedures had not been carried out.

On examination, she had generalized and buccal hyperpigmentation. Her height was $175 \mathrm{~cm}$, weight $48 \mathrm{~kg}$ and BMI $15.7 \mathrm{~kg} / \mathrm{m}^{2}$. Her blood pressure was $160 / 90 \mathrm{mmHg}$ without postural hypotension and there was no significant discrepancy in the pressures between the right and left limbs. Her pulses were palpable in all extremities. There were no palpable masses or renal bruit in the abdomen. She had female external genitalia, but there were no secondary sexual characteristics. Breast and pubic hair were both tanner stage 1 . 
Figure 1. Adrenal steroid synthesis. Deficiency in 17 á hydroxylase/17,20-lyase results in accumulation of deoxycorticosterone (DOC) and consequent hypertension; reduced cortisol and androgen production

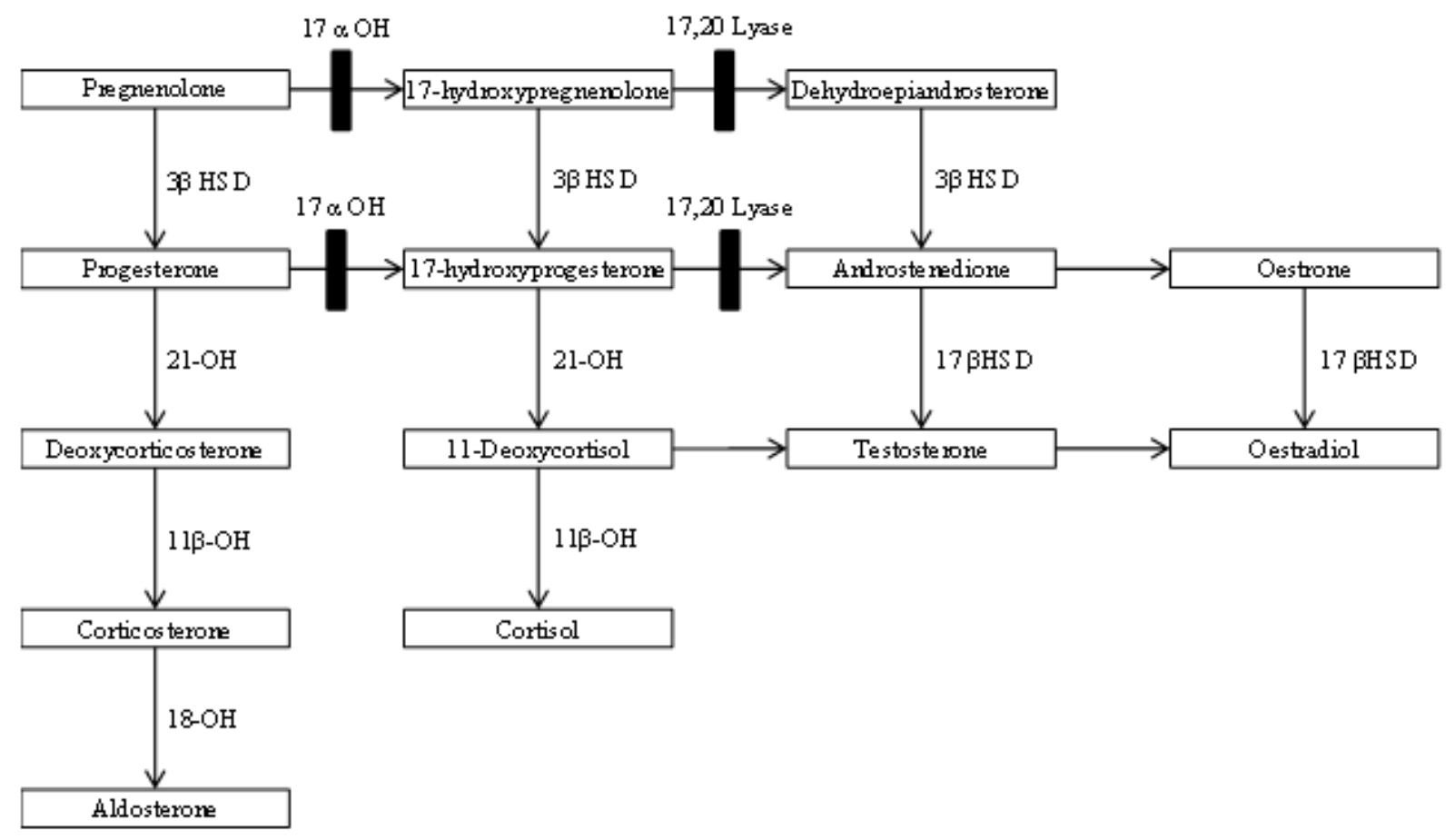

Table 1. Results of biochemical investigations

\begin{tabular}{|c|c|c|c|}
\hline Laboratory test & Results & \multicolumn{2}{|c|}{ Reference range } \\
\hline Cortisol (9 a.m.) & $78 \mathrm{nmol} / \mathrm{L}$ & \multicolumn{2}{|c|}{$180-620 \mathrm{nmol} / \mathrm{L}$} \\
\hline 17-hydroxyprogesterone & $0.30 \mathrm{ng} / \mathrm{mL}$ & \multicolumn{2}{|c|}{$0.5-2.1 \mathrm{ng} / \mathrm{mL}$} \\
\hline ACTH & $1389 \mathrm{pg} / \mathrm{mL}$ & \multicolumn{2}{|c|}{$0-60 \mathrm{pg} / \mathrm{mL}$} \\
\hline Progesterone & $9.68 \mathrm{ng} / \mathrm{mL}$ & $\begin{array}{l}\text { Follicular } \\
\text { Luteal } \\
\text { Males }\end{array}$ & $\begin{array}{l}<9.6 \mathrm{ng} / \mathrm{mL} \\
45-285 \mathrm{ng} / \mathrm{mL} \\
2.9-13 \mathrm{ng} / \mathrm{mL}\end{array}$ \\
\hline $\begin{array}{l}\text { DHEAS (Dehydroepiandrosterone } \\
\text { sulphate) }\end{array}$ & $<15.0 \mu \mathrm{g} / \mathrm{dL}$ & $\begin{array}{l}\text { Females } \\
\text { Males }\end{array}$ & $\begin{array}{l}44-332 \mu \mathrm{g} / \mathrm{dL} \\
89-457 \mu \mathrm{g} / \mathrm{dL}\end{array}$ \\
\hline Testosterone & $<0.20 \mathrm{ng} / \mathrm{mL}$ & $\begin{array}{l}\text { Females } \\
\text { Males }\end{array}$ & $\begin{array}{l}1.7-9 \mathrm{ng} / \mathrm{mL} \\
29-100 \mathrm{ng} / \mathrm{mL}\end{array}$ \\
\hline Oestradiol & $11.0 \mathrm{pg} / \mathrm{mL}$ & $\begin{array}{l}\text { Follicular } \\
\text { Luteal } \\
\text { Males }\end{array}$ & $\begin{array}{l}\text { 60-936 pg/mL } \\
648-3960 \mathrm{pg} / \mathrm{mL} \\
0-688 \mathrm{pg} / \mathrm{mL}\end{array}$ \\
\hline FSH (Follicular Stimulating Hormone) & $86.1 \mathrm{mIU} / \mathrm{mL}$ & $\begin{array}{l}\text { Follicular } \\
\text { Luteal } \\
\text { Males }\end{array}$ & $\begin{array}{l}0.5-5 \mathrm{mIU} / \mathrm{mL} \\
2-8 \mathrm{mIU} / \mathrm{mL} \\
1.4-18 \mathrm{mIU} / \mathrm{mL}\end{array}$ \\
\hline LH (Luteinizing Hormone) & $102.0 \mathrm{mIU} / \mathrm{mL}$ & $\begin{array}{l}\text { Follicular } \\
\text { Luteal } \\
\text { Males }\end{array}$ & $\begin{array}{l}\text { 3-12 mIU/mL } \\
\text { 3-16 mIU/mL } \\
\text { 3-8 } \mathrm{mIU} / \mathrm{mL}\end{array}$ \\
\hline Renin (Upright) & $3.45 \mathrm{pg} / \mathrm{mL}$ & \multicolumn{2}{|c|}{$5.41-34.53 \mathrm{pg} / \mathrm{mL}$} \\
\hline Aldosterone (Upright) & $255 \mathrm{pg} / \mathrm{mL}$ & \multicolumn{2}{|c|}{$34.7-275 \mathrm{pg} / \mathrm{mL}$} \\
\hline
\end{tabular}


Laboratory investigations revealed persistently low potassium levels (ranging between 2.5 to $3.5 \mathrm{mmol} / \mathrm{l}$ ) with normal renal and liver profiles. She had a low serum cortisol, low 17-hydroxyprogesterone with very high ACTH levels. Furthermore, her adrenal androgens (DHEA and testosterone) and oestradiol levels were low with elevated gonadotrophins. Plasma renin activity was low but her aldosterone remained in upper normal level (Table 1). DOC and 11-deoxycortisol levels could not be performed due to unavailability of tests.

Chromosomal analysis revealed a male karyotype of 46, XY. Contrast CT of the abdomen did not show a uterus, ovaries or testis. There was hyperplasia of the left adrenal gland.

A clinical diagnosis was made through these clinical, imaging and laboratory data, which were consistent with CAH due to $17 \alpha$-hydroxylase /17,20-lyase deficiency in a genotypic male. Testing for specific gene mutations was unavailable.

\section{Discussion}

Congenital adrenal hyperplasia due to $17 \alpha \mathrm{OH} / 17,20$ -lyase deficiency leads to deficiency in glucocorticoid, adrenal androgens and sex steroid synthesis with a subsequent increase in ACTH and gonadotropin levels. Concomitant mineralocorticoid excess results in hypokalaemic hypertension. Although these patients have low cortisol levels, weaker glucocorticoid corticosterone in excess prevents adrenal crisis (4). This patient had the classic clinical features and laboratory data consistent with the diagnosis of CAH due to $17 \alpha$ hydroxylase/17,20 -lyase deficiency. Her ACTH levels were very high causing generalized hyperpigmentation.

It is interesting to note that levels of aldosterone are suppressed in most cases in spite of the increased levels of corticosterone and DOC. The favoured explanation is that significantly increased DOC and corticosterone leads to expansion of blood volume which in turn suppress plasma renin and aldosterone secretion (5). On the other hand, a considerable number of cases of $17 \alpha \mathrm{OH}$ deficiency have normal or elevated aldosterone levels despite low plasma renin activity (6) as in this patient. However, it is likely that aldosterone production in these patients was primarily ACTH-mediated rather than via the reninangiotensin system. It is also likely that the seemingly high aldosterone concentrations may be due to crossreactions between aldosterone and other mineralocorticoid precursors (7).

Affected 46, XX females have normal female internal and external genital tracts, but the ovaries cannot secrete oestrogens at puberty, resulting in absent breast development and hypogonadism with elevated gonadotrophins. Affected 46, XY individuals with complete combined $17 \alpha \mathrm{OH} / 17,20$-lyase deficiency usually have female external genitalia. This patient probably has complete combined $17 \alpha \mathrm{OH} / 17,20$-lyase deficiency as she also had female external genitalia and 46, XY karyotype. Testes may usually be intra-abdominal, in the inguinal canal or in the labio-scrotal folds although they were not found in this patient either radiologically or laparoscopically.

Complete $17 \alpha \mathrm{OH} / 17,20$ lyase deficiency is associated with a variety of mutations in the CYP 17 gene with resultant loss of function of enzyme. Due to lack of availability genetic mutation analysis, it was not performed in this patient.

Partial forms of combined $17 \alpha \mathrm{OH} / 17,20$-lyase deficiency have been described (8). These conditions most frequently manifest as a 46, XY infants with ambiguous genitalia or severe hypospadiasis, in whom the steroid profile is consistent with the diagnosis. $46, \mathrm{XX}$ individuals may present with menstrual problems or with infertility (9). Hypertension may or may not be present. Isolated 17,20-lyase deficiency has been reported in small number of patients. These 46, XY individuals usually have genital ambiguity, normal secretion of glucocorticoids and mineralocorticoids with marked reduction in sex steroids $(10,11)$.

Management of CAH due to $17 \alpha$ OHdeficiency comprises glucocorticoid replacement and normalization of ACTH, which in turn will remove the drive for oversecretion of deoxycorticosterone and corticosterone. This in most cases will bring about remission of hypertension and hypokalaemia. This patient was started on steroid replacement therapy; hydrocortisone $5 \mathrm{mg}, 2.5 \mathrm{mg}, 2.5 \mathrm{mg}$ at 6 a.m, 12 noon and $6 \mathrm{p} . \mathrm{m}$ while monitoring the potassium, blood pressure and ACTH levels. 'She' chose to remain a phenotypic female after discussing with the parents.

\section{Conclusion}

The diagnosis of $17 \alpha \mathrm{OH} / 17,20$-lyase deficiency is generally delayed, due to the low incidence of adrenal crisis and other severe symptoms in untreated patients. A high index of clinical suspicion is necessary when evaluating patients with 46, XY DSD (Disorders of sex determination) and adolescents with sexual infantilism. The diagnosis is strongly supported by the discovery of hypertension along with hypokalaemia.

\section{References}

1. Yanase T, Simpson ER, Waterman MR. $17 \alpha$-Hydroxylase/ 17,20 lyase deficiency: From clinical investigation to molecular definition. Endocr Rev 2004; 12: 91-108.

2. Bradshaw KD, Waterman MR, Couch RT, Simpson ER, Zuber MX. Characterization of complementary deoxyribonucleic acid for human adrenocortical 17 alpha- 
hydroxylase: a probe for analysis of 17 alpha-hydroxylase deficiency. Molecular Endocrinology 1987; 1: 348-54.

3. Sparkes RS, Klisak I, Miller WL. Regional mapping of genes encoding human steroidogenic enzymes: P450 scc to 15q23-q24, adrenodoxin to 11q22; adrenodoxinreductase to 17q24-q25; and P450c17 to 10q24-q25. DNA Cell Biol 1991; 10(5): 359-65.

4. Polonsky KS, Larsen PR, Kronenberg HM, Melmed S, Williams D. Textbook of Endocrinology. 12th ed. 2011; 23: 900-2.

5. Takeda Y, Yoneda T, Demura M, et al. Genetic analysis of the cytochrome P-450c17alpha (CYP17) and aldosterone synthase (CYP11B2) in Japanese patients with 17 alphahydroxylase deficiency. Clin Endocrinol (Oxf) 2001; 54: 751-8.

6. Shima H, Kawanka H, Yabumoto Y, et al. A case of 17alphahydroxylase deficiency with chromosomal karyotype 46, $\mathrm{XY}$ and high plasma aldosterone concentration. Int Urol Nephrol 1991; 23: 611-8.
7. Di Cerbo, A, Biason-Lauber, A, Savino, M. et al. Combined 17alpha-hydroxylase/17,20-lyase deficiency caused by Phe93Cys mutation in the CYP17gene. J Clin Endocrinol Metab 2002; 87: 898-905.

8. Yanase T, Kagimoto M, Suzuki S, Hashiba K, Simpson ER, Waterman MR. Deletion of a phenylalanine in the Nterminal region of human cytochrome P-450 (17 alpha) results in partial combined 17 alpha-hydroxylase/17,20lyase deficiency. J Biol Chem 1989; 264(30): 18076-82.

9. Levran D, Shlomo-Ben I, Pariente C, Dor J, Shlomo M, Weissman A. Familial Partial 17,20-Desmolase and $17 \alpha-$ Hydroxylase Deficiency Presenting as Infertility. Journal of Assisted Reproduction and Genetics 2003; 20(1): 21-8.

10. Tian Q, ZhangY, Lu Z. Partial 17 alpha-hydroxylase/17,20lyase deficiency - clinical report of five Chinese 46, XX cases. Gynecol Endocrinol 2008; 24(7): 362-7.

11. Geller DH, Auchus RJ, Mendonca BB, et al. The genetic and functional basis of isolated 17,20 lyase deficiency. Nat Genet 1997; 17: 201-5. 